\title{
111. On the Seismic Activity of Central Japan with Special Reference to the Cause of the Great Mino-Owari Earthquake of 1891.
}

\author{
By Akitune Imamura, M. I. A. \\ Seismological Institute, Tokyo Imperial University.
}

(Comm. July 12, 1928.)

Earthquakes originating in Central Japan, whether inland or submarine, may roughly be divided into two systems according as they emerge from the Pacific side in the south (district S, Fig. 1) or from a

Fig. 1.

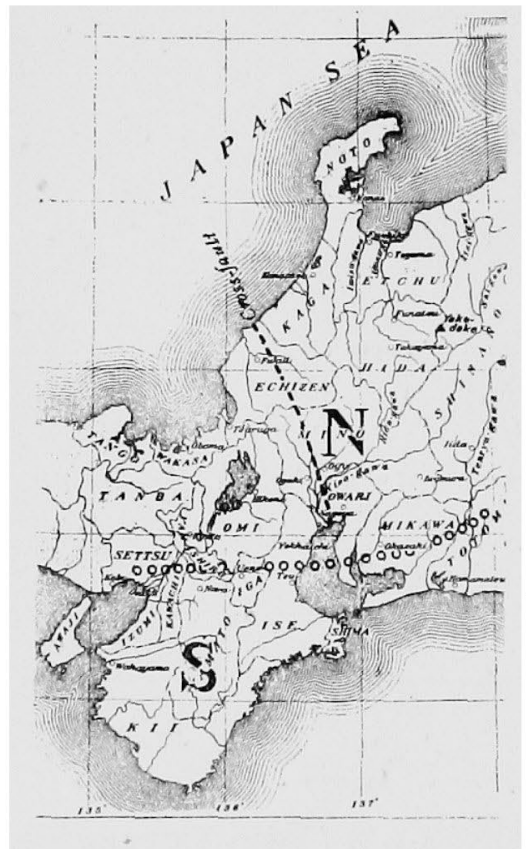
tract in the north with the province of Mino as its approximate centre (district $\mathrm{N}$ ). Forces, orogenic or epirogenic, causing an upheaval in the southern part of district $S$, or in the ocean bed off its Pacific coast may be put down as the source of seismic activity in this district. On the other hand, those forces, working to break the main island of Japan into two along the fault line, which for lack of a better word the writer will call the cross-fault, may be the source of the seismic activity in district N. (See Fig. 2.)

Bearing these in mind, and tabulating the large earthquakes that have occurred in these districts during the past 1250 years, a recurrence of activity is noticeable in each district. In Table I the leading member of each cycle, which is generally a non-local destructive earthquake, is printed in heavy type, while those that precede it and follow it, which are mostly local destructive or semidestructive shocks, are shown in ordinary type.

Before going further it may be well for us to see how the seismic activity of district $\mathrm{N}$ was influenced by the great Mino-Owari earthquake of 1891. This tremendous shock, which resulted in the loss of 7273 lives and destruction of 142,177 houses, was caused, according to Prof. B. Koto, ${ }^{1)}$ by a gigantic fault known as the Midori or Neo-valley fault. The track of the fault extended from Gongenyama in the north $(A)$ to Nisikatabira $\left(a^{\prime}\right)$ in the southeast, though it was later proved to 


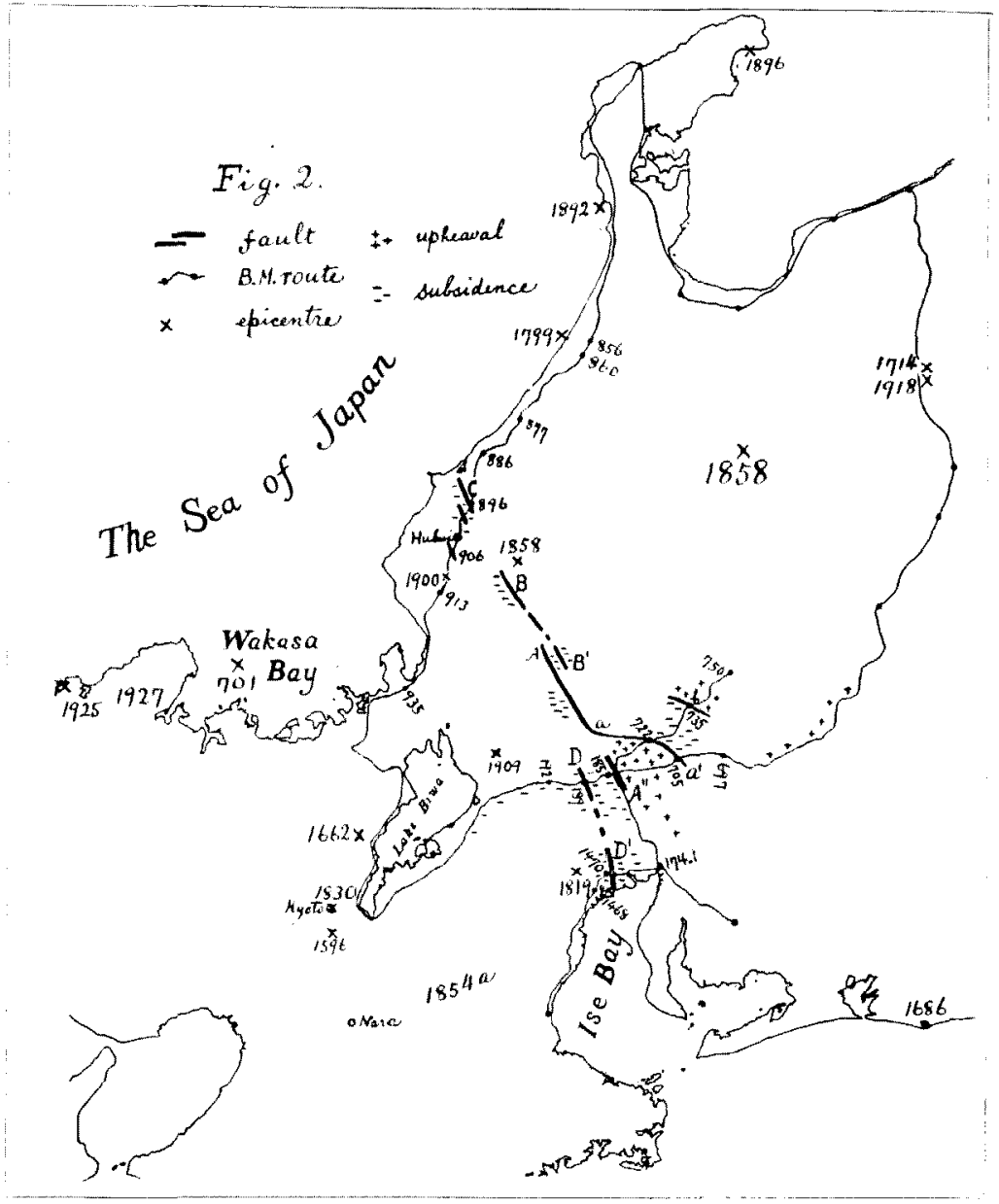

Table I.

\begin{tabular}{|c|c|c|}
\hline District $\mathrm{N}$ & Neutral & District $\mathrm{S}$ \\
\hline \multirow{3}{*}{$\begin{array}{l}701^{*}, \mathbf{7 4 5}, 762 \text { (Mino) } \\
863 \text { (Ettyu, Etigo) }\end{array}$} & & 684 \\
\hline & & 715 (Mikawa, Totomi) \\
\hline & $\begin{array}{l}828 \text { \& } 856 \text { (Kyoto), } \\
868 \text { (Harima), } \\
881 \text { (Kyoto) }\end{array}$ & 887 \\
\hline \multirow[t]{2}{*}{976 (Yamasiro, Oomi) } & 938 (Kyoto) & \\
\hline & 1096 (Nara) & \\
\hline \multirow[t]{3}{*}{1185} & 1177 (Nara) & 1180 (Kumano) \\
\hline & 1350 (Kyoto) & 1331 (W. Kii), 1361 \\
\hline & $\begin{array}{l}1494 \text { (Nara) } \\
1510 \text { (Settu) }\end{array}$ & 1498 \\
\hline $\begin{array}{l}\text { 1586, } 1596 \text { (Husimi) } \\
1639 \text { (Hukui), } 1662 \text { (Yamasiro) }\end{array}$ & & $\begin{array}{l}1585 \text { (Totomi), 1605, } \\
1686 \text { (Hamamatu) }\end{array}$ \\
\hline 1714 (Oomati), 1799 (Kaga) & & 1707 \\
\hline $\begin{array}{l}1819 \text { (Kuwana), } 1830 \text { (Kyoto), } \\
1858 \text { (Hida), 1891, } \\
1892 \text { \& } 1896 \text { (Noto), } \\
1900 \text { (Sabae), } 1909 \text { (Anegawa), } \\
1918 \text { (Oomati), } 1925^{*}, 1927^{*}\end{array}$ & & $\begin{array}{l}1854 \text { a (Iga, Ise, Yamato) } \\
1854 \text { b, } \\
1899 \text { (Kumano) }\end{array}$ \\
\hline
\end{tabular}


extend as far northwards as Hukui. The late Prof. F. Omori investigated another branch fault which was found to be essentially coincident in its $\mathrm{N}$. portion with the $\mathrm{N}$. extention of the Midori fault just mentioned, but differing from that of Prof. Koto in its S. part $\left(\mathrm{B}^{\prime}\right)$, the latter running parallel to the Midori fault proper as shown in Fig. 2.

Quite recently, by the courtesy of Major-General H. Omura, Director of the Military Land Survey Department, the writer was furnished with the results of precise levellings repeatedly carried out, before and after the great earthquake, over the different routes in the seismic area. These data, together with those that were published in 1903 , were extremely valuable in the present investigation. The routes and results of surveys adopted are shown in Fig. 2 and 3 respectively. Upon close examination it was noticed that the intersections of the main fault or its branch lines and the levelling routes come out as follows:

Fig. 3.

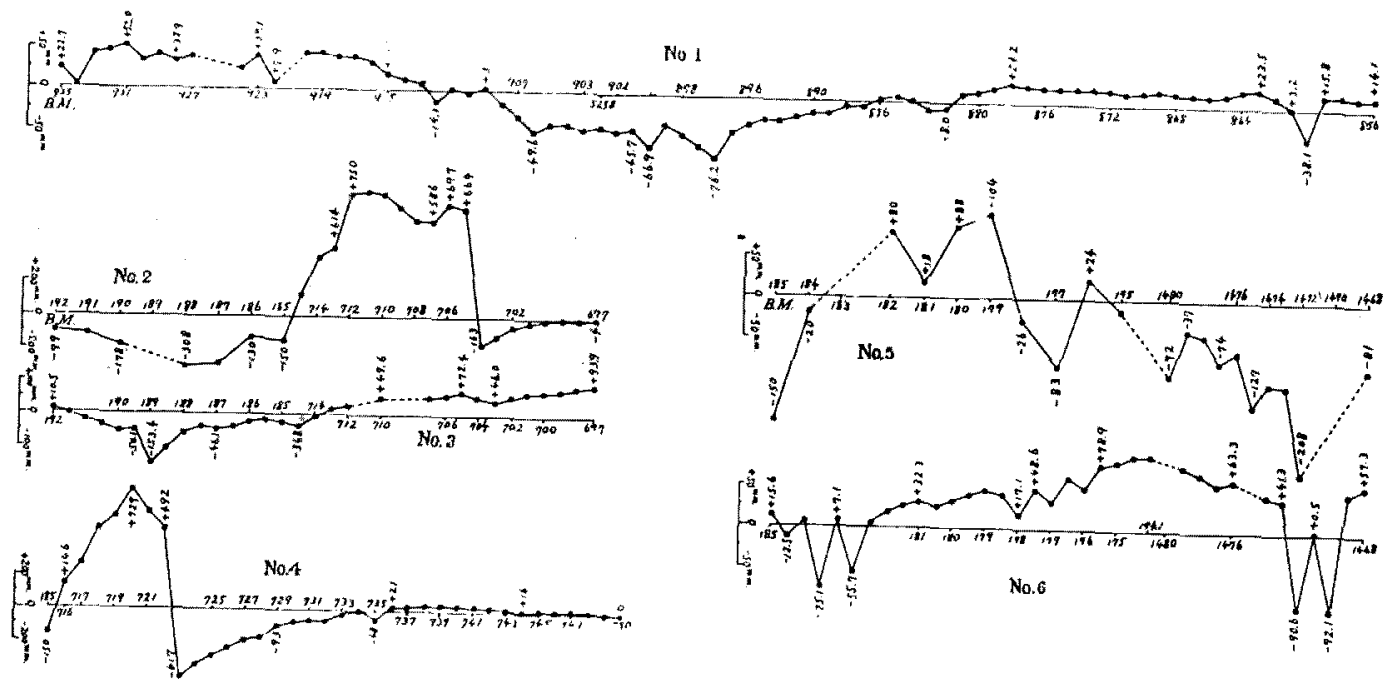

Table II.

\begin{tabular}{c|c|c|c|c}
\hline Curve no. & Route & B.M. no. & $\begin{array}{c}\text { Change in } \\
\text { heights }\end{array}$ & Period \\
\cline { 2 - 3 } 1 & Hukui & 896 & -76 & $\mathrm{~mm}$. \\
2 & Tarui - Kano-Mikasa & 188 & -308 & $1890-1917$ \\
3 & do. & 189 & -153 & $1886-1896$ \\
2 & do. & $185-715$ & 278 & $1889-1917$ \\
2 & do. & $705-704$ & 827 & do. \\
4 & Kano-Simohara & $722-723$ & 909 & $1890-1895$ \\
4 & do. & $735-736$ & 69 & do. \\
5 & Kano-Atuta-Kuwana & 1472 & -208 & $1888-1895$ \\
6 & do. & do. & -91 & $1895-1918$ \\
6 & do. & 1470 & -92 & do. \\
\hline
\end{tabular}


On considering these results the writer believes that the fault which occurred with the 1891 earthquake crossed the island from the head of Ise Bay in the south, trending towards NNW, up to the Sea of Japan in the north. The track of this cross-fault consisted of three or four detached segments arranged in an echelon shape with the southern segments in the tract of tension. The regions to the west of the track underwent, in general, subsidence with southward shift relatively against the east side, though this rule is violated by the appearance of two branches on the latter side $\left(a a^{\prime}\right.$ and $b$ ).

It is now easy to imagine how that gigantic force, which caused the tremendous 1891 earthquake was applied there. The force might possibly have been directed from the NW, or NNW, towards the SE, or SSE, compressional on the $\mathrm{N}$. side and tensional on the $\mathrm{S}$. side so as to widen out Ise Bay like a fan with the pin holding the sticks together somewhere near the centre of the cross-fault. Further, displacements occurred along the cross-fault with the W. side downwards towards the south, lifting the high land composing the Japan-Alps in the east by as much as $20 \mathrm{~cm}$. and lowering the low Wakasa Bay-Biwa Lake-Ise Bay line in the west by as much as $4-10 \mathrm{~cm}$. According to Dr. K. Wadati, ${ }^{1)}$ a zone of deep-seated earthquakes runs along this line, possibly due to the same agency.

In turning again to Table I, it will be seen that the 1891 earthquake was the leader, so to speak, of the recent activity, the local shocks which took place from the beginning of the 19th century up to the present day, being either its forerunners or followers. ${ }^{2)}$ Of earthquakes similar in character, and equal in magnitude, to the 1891 earthquake there was only one, namely, the 745 earthquake, those of 1185 and 1586 showing more the characteristics of deep-seated earthquakes. It must also be remarked that large earthquakes originating in the western part of Wakasa Bay, or to the west of it (marked with asterisk, Tab. I) took place in the same epochs as those of the 745 and 1891 earthquakes respectively.

It is the writer's opinion that the seismic activity of the northern half of Central Japan is much under the sway of that gigantic force which is constantly being applied there, and causes as its cumulative effect, cataclysms so violent, like the experience of 37 years ago, as would seem to break the main island of Japan into two along the line of the cross-fault.

1) Wadati : Geop. Mag. I (1928), No. 4.

2) Compare Imamura: Jap. Jour. Astro. \& Geop., V (1928), No. 3. 